\title{
Driver Device
}

National Cancer Institute

\section{Source}

National Cancer Institute. Driver Device. NCI Thesaurus. Code C49931.

A computer interface designed to control the interaction between a CPU and a peripheral device. 